\title{
Analisis Pembiayaan pada Program Kesehatan Ibu dan Anak Melalui Metode Health Account di Kabupaten Jember
}

\author{
Analysis on Financing on Maternal and Child Health Program Through Health \\ Account Method in Jember
}

\author{
Geofani Armahedi ${ }^{1}$, Eri Witcahyo ${ }^{1}$, Sri Utami ${ }^{1}$ \\ ${ }^{1}$ Departemen Administrasi dan Kebijakan Kesehatan, Fakultas Kesehatan Masyarakat, Universitas Jember \\ Korespondensi: Eri Witcahyo,, \\ e-mail:ewitcahyo@unej.ac.id
}

\begin{abstract}
Abstrak
Kesehatan Ibu dan Anak (KIA) merupakan permasalahan kesehatan yang belum tuntas di Indonesia. Ibu dan anak adalah anggota keluarga yang perlu mendapatkan perhatian serta prioritas dalam usaha penyelenggaran kesehatan. Tahun 2012 terdapat enam provinsi yang menjadi fokus pemerintah dalam mengatasi permasalahan kematian ibu yang salah satunya Jawa Timur. Kabupaten Jember menjadi salah satu Kabupaten di Jawa Timur yang masih mengalami permasalahan KIA. Penambahan anggaran dalam upaya peningkatan kesehatan ibu dan anak belum berjalan secara optimal di Kabupaten Jember. Oleh karena itu, perlu dilakukan penelitian dengan pendekatan Health Account terkait KIA di Kabupaten Jember. Jenis penelitian yang digunakan adalah penelitian deskriptif. Unit analisis pada penelitian ini adalah intitusi yang melakukan kegiatan langsung maupun tidak langsung terhadap program KIA pada tahun 2018 dengan fokus anggaran yang berada pada tingkat daerah. Hasil penelitian menunjukkan pola belanja pada setiap program kesehatan banyak digunakan untuk belanja investasi dan anggaran banyak diprioritaskan untuk belanja investasi pada kegiatan tidak langsung. Saran yang diberikan adalah pemerintah Kabupaten Jember menyusun kebijakan yang diarahkan pada pembangunan berparadigma sehat dan membangun sistem informasi manajemen keuangan daerah yang terintegrasi, dan juga harus membuat payung hukum untuk melembagakan pelaksanaan Health Account ditingkat daerah.

Kata kunci: kesehatan ibu dan anak, pembiayaan kesehatan, health account.
\end{abstract}

\begin{abstract}
Maternal and Child Health (MCH) is unresolved health problems in Indonesia. Mother and child are family members who need attention and priority in delivery of health. In 2012, there were six provinces that were focus of government in resolve problems of maternal mortality, one of them was East Java. Jember District is one of district in East Java that is still having problems with MCH. The addition of the budget in increasing maternal and child health has not been running optimally in Jember. Therefore, it is necessary to research with Health Account approach related to $\mathrm{MCH}$ in Jember District. This type of research was descriptive research. The unit of analysis in this research was the institution that carried out direct or indirect activities on the MCH program in 2018 with an appropriate budget focus at the regional level. The results of research showed that expenditure patterns on every program were widely used for investment expenditure and the budget was prioritized for investment expenditure in indirect activities. The advice given is that Jember District Government develops policies directed at healthy paradigm development and builds an integrated financial management information system, and must also create a legal protection to institutionalize implementation of Health Accounts at distrcit level.

Keywords: maternal and child health, fealth financing, health account
\end{abstract}

\section{Pendahuluan}

Kesehatan Ibu dan Anak (KIA) merupakan salah satu permasalahan kesehatan yang belum tuntas di Indonesia. Ibu dan anak adalah anggota keluarga yang perlu mendapatkan perhatian serta prioritas dalam usaha penyelenggaran kesehatan, hal ini disebabkan ibu dan anak terkategori sebagai kelompok rentan pada kualitas kesehatan suatu keluarga. Keberhasilan dalam upaya peningkatan kualitas kesehatan ibu dapat dilihat melalui indikator Angka Kematian Ibu (AKI). Pada kesehatan anak yang menjadi indikator utama adalah Angka Kematian Bayi (AKB) (Depkes RI,2017). 
Menurut hasil Survei Penduduk Antar Sensus (SUPAS) 2015 di Indonesia AKI mengalami penurunan dari tahun 2012 yaitu dari angka 359 per 100.000 kelahiran hidup menjadi 305 per 100.000 kelahiran hidup dan AKB mencapai angka 22,23 per 1.000 kelahiran hidup (Depkes RI,2017). Hal ini menyebabkan AKI dan AKB di Indonesia perlu mendapatkan perhatian karena pembangunan kesehatan yang berdasarkan pada target global Sustainable Developmet Goals (SDGs) berusaha untuk mengakhiri permasalahan kematian ibu dan bayi pada tahun 2030 yang tercantum pada tujuan nomor tiga, yaitu menurunkan AKI hingga 70 per 100.000 kelahiran hidup dan menurunkan AKB hingga 12 per 1.000 kelahiran hidup (ILO, 2018). Tahun 2012 terdapat enam provinsi yang menjadi fokus pemerintah dalam mengatasi permasalahan kematian ibu, di antaranya Sumatera Utara, Banten, Jawa Barat, Jawa Tengah, Jawa Timur, dan Sulawesi Selatan. Kabupaten Jember menjadi salah satu Kabupaten di Jawa Timur yang masih mengalami permasalahan KIA. Hal ini dapat dilihat dari adanya kenaikan AKI sejak tahun 2014 hingga tahun 2017. Pada tahun 2014 AKI berada pada posisi 86,13 per 100.000 kelahiran hidup, sedangkan pada tahun 2015 mengalami kenaikan pada posisi 87,73 per 100.000 kelahiran hidup, sementara pada tahun 2016 mencapai 91,01 per 100.000 kelahiran hidup, dan puncaknya pada tahun 2017 yaitu berada pada angka 135,3 per 100.000 kelahiran hidup (Dinkes Kabupaten Jember, 2017). Sedangkan untuk AKB pada tahun 2017 mengalami kenaikan dibandingkan tahun 2016, yang awalnya 6,01 per 1.000 kelahiran hidup mengalami kenaikan menjadi 6,41 per 1.000 kelahiran hidup (Dinkes Kabupaten Jember, 2017).

Kesehatan Ibu dan Anak menjadi salah satu prioritas masalah kesehatan yang harus menjadi perhatian khusus oleh pemerintah maupun pemerintah daerah. Permenkes RI No 39 Tahun 2016 tentang
Pedoman Penyelenggaraan Program Indonesia Sehat Dengan Pendekatan Keluarga tertuang bahwa dalam rangka mempercepat pembangunan kesehatan nasional untuk mencapai Indonesia Sehat perlu dilakukan penguatan terhadap subsistem SKN (Sistem Kesehatan Nasional), yang salah satunya adalah subsistem pembiayaan kesehatan. Pembiayaan dibidang kesehatan merupakan salah satu permasalahan yang memerlukan perhatian khusus. Pembiayaan kesehatan di Indonesia masih banyak memiliki permasalahan, selain pembiayaan dibidang kesehatan relatif kecil juga penggunaan dan pengalokasian belum dilakukan secara efektif dan efisien. Permasalahan yang sering kali terjadi adalah pengalokasian tidak sesuai dengan prioritas kesehatan serta perilaku belanja masih cenderung pada barang investasi dan kegiatan tidak langsung, akibatnya biaya operasinal dan biaya untuk kegiatan langsung menjadi berkurang (PPJK Kemenkes \& PKEKK FKM UI, 2016). Menurut penelitian oleh Priagung \& Mafudi (2016) penyerapan anggaran berpengaruh signifikan terhadap kinerja keuangan organisasi publik. Birokrasi memiliki kewajiban untuk mengelola keuangan secara tepat sasaran serta tepat waktu sehingga realisasi anggaran dapat terserap secara baik.

Berdasarkan Dokumen Pelaksanaan Perubahan Anggaran Satuan Kerja Perangkat Daerah (DPPA SKPD) Pemerintah Kabupaten Jember Tahun Anggaran 2017 untuk anggaran belanja langsung yang dilakukan oleh dinas kesehatan Kabupaten Jember dalam upaya program KIA tahun 2017 mencapai Rp 2.120.406.500,00. Anggaran tersebut mengalami peningkatan $54,11 \%$ atau $\mathrm{Rp}$ 744.542.500,00 dari tahun 2016. Penambahan anggaran dalam upaya peningkatan kesehatan ibu dan anak ternyata belum berjalan secara optimal, dibuktikan dengan meningkatnya AKI dan AKB pada tahun 2017 dari tahun sebelumnya. Secara realita terdapat beberapa permasalahan mengenai pembiayaan 
kesehatan pada tingkat Kabupaten/Kota, seperti pemanfaatan anggaran untuk belanja fisik, kurangnya anggaran untuk biaya operasional, realisasi anggaran pemerintah yang mengalami keterlambatan dan lain-lain. Dalam proses identifikasi anggaran pada program Kesehatan Ibu dan Anak (KIA) dapat dilakukan dengan Health Account (PPJK Kemenkes \& PKEKK FKM UI, 2016).

Health Account memberikan deskripsi sistematis aliran keuangan terkait dengan konsumsi barang dan jasa perawatan kesehatan. Tujuannya adalah untuk menggambarkan sistem kesehatan secara perspektif pembelanjaan. Salah satu prioritasnya adalah mengembangkan data yang dapat diandalkan dan tepat waktu yang dapat dibandingkan di seluruh negara dan dari waktu ke waktu. Hal ini sangat diperlukan untuk melacak tren dalam belanja kesehatan, yang dapat digunakan sebagai asumsi pertumbuhan pada masa yang akan datang (OECD, 2011:20). Health Account juga dapat membandingkan peran dan fungsi antara instansi pemerintah, swasta, serta perusahaan asuransi kesehatan dalam menyediakan pelayanan yang dibutuhkan (Zakeri et al., 2015). Untuk mengetahui keadaan pembiayaan kesehatan pada program KIA secara menyeluruh maka perlu digunakan pendekatan Health Account yang berfokus pada anggaran pada daerah tingkat II sehingga dapat memberikan dampak tidak langsung pada capaian program KIA, maka perlu dilakukan penelitian tentang pembiayaan kesehatan pada program Kesehatan Ibu dan Anak (KIA) melalui metode Health Account (HA) di Kabupaten Jember.

\section{Metode Penelitian}

Jenis penelitian yang digunakan pada penelitian ini adalah penelitian deskriptif. Unit analisis pada penelitian ini adalah intansi yang melakukan kegiatan langsung maupun tidak langsung terhadap program KIA pada tahun 2018 dengan fokus anggaran yang berada pada tingkat aerah. Instansi dari sektor pemerintahan yaitu, Dinas Kesehatan Kabupaten Jember, Dinas Pendidikan Kabupaten Jember, dan Dinas Pemberdayaan Perempuan, Perlindungan Anak dan Keluarga Berencana. Adapun untuk instansi dari sektor swasta yaitu LSM GAIN. Data yang dikumpulkan yaitu data primer dan data sekunder. Data primer pada penelitian ini didapat dengan melakukan wawancara dengan menggunakan pedoman wawancara. Data sekunder pada penelitian ini didapat melalui studi dokumentasi dari data laporan keuangan dengan menggunakan lembar check list dalam prosesnya.

Pengumpulan data dilakukan melalui wawancara dan studi dokumentasi. Teknik penyajian data dilakukan dengan tabulasi data dengan disertai penjelasan dalam bentuk narasi. Analisis data dilakukan sesuai dengan langkah pada Health Account dengan menggunakan analisis univariat dan bivariat.

\section{Hasil}

Gambaran sumber biaya (financing sources), pengelola anggaran (financing agent), dan penyelenggara pelayanan (health provider) Sumber biaya diidentifikasi dari dua sumber yaitu dana publik atau dana non publik yang selanjutnya ditelaah institusi yang melakukan pengelolaan dan menerima dana untuk mengetahui pengelola anggaran dan penyelenggara pelayanan yaitu institusi yang menggunakan dana untuk melakukan prosuksi barang dan jasa pelayanan kesehatan. 
Tabel 1. Gambaran Sumber Biaya, Pengelola Anggaran, dan Penyelenggara Pelayanan

\begin{tabular}{|c|c|c|c|}
\hline Kode & Sumber Biaya & Jumlah Belanja (Rp) & $\%$ \\
\hline FS.1.1.2.2.1 & $\begin{array}{l}\text { APBD Kab/Kota (DBH, DAU, DAK, } \\
\text { PAD) }\end{array}$ & 44.902 .535 .500 & 95,72 \\
\hline \multirow{3}{*}{ FS.2.4.2.1 } & Donor: Hibah kepada Swasta & 2.009 .848 .755 & 4,28 \\
\hline & Grand Total & 46.912.384.255 & 100,00 \\
\hline & Pengelola Anggaran & Jumlah Belanja (Rp) & $\%$ \\
\hline FA.1.2.2.1 & Dinas Kesehatan & 41.466 .264 .000 & 88,39 \\
\hline FA.1.2.2.12 & Dinas Pendidikan & 2.332 .202 .000 & 4,97 \\
\hline FA.1.2.2.9 & Dinas Pemberdayaan Perempuan dan KB & 1.104 .069 .500 & 2,35 \\
\hline \multirow[t]{3}{*}{ FA.4 } & Yayasan/Lembaga Sosial (Nirlaba) & 2.009 .848 .755 & 4,28 \\
\hline & Grand Total & 46.912 .384 .255 & $\mathbf{1 0 0 , 0 0}$ \\
\hline & Penyelenggara Pelayanan & Jumlah Belanja (Rp) & $\%$ \\
\hline HP.1.1.3 & Rumah Sakit Umum Kabupaten/Kota & 1.329 .217 .000 & 2,83 \\
\hline HP.6.1.1 & Puskesmas & 4.169 .500 .000 & 8,89 \\
\hline HP.7.1.5.1 & Dinas Kesehatan & 36.221 .504 .000 & 77,21 \\
\hline HP.7.1.5.12 & Dinas Pendidikan & 2.332 .202 .000 & 4,97 \\
\hline HP.7.1.5.9 & $\begin{array}{l}\text { Badan Pemberdayaan Perempuan dan } \\
\text { KB }\end{array}$ & 850.112 .500 & 1,81 \\
\hline \multirow[t]{2}{*}{ HP.7.4 } & Penyelenggara Administrasi lainnya & 2.009 .848 .755 & 4,28 \\
\hline & Grand Total & 46.912 .384 .255 & 100,00 \\
\hline
\end{tabular}

Berdasarkan Tabel 1 dapat diketahui bahwa sumber pembiayaan program KIA di Kabupaten Jember bersumber dari anggaran APBD Kabupaten/Kota dan dari pihak swasta. Sumber pembiayaan terbesar berasal dari APBD Kabupaten/Kota yaitu sebesar 95,72\%. Pembiayaan program KIA yang berasal dari Lembaga Swadaya Masyarakat (LSM) hanya sebesar 4,28\% yang berasal dari donor luar negeri. Dinas Kesehatan menjadi pengelola terbesar terhadap anggaran program KIA $(88,39 \%)$. Dinas Pendidikan mengelola anggaran hanya sebesar $4,97 \%$ yang sementara pihak swasta yaitu LSM mengelola anggaran sebesar 4,28\%. Dinas Pemberdayaan Perempuan Perlindungan Anak dan Keluarga Berencana (DP3AKB) mengelola anggaran untuk KIA sebesar 2,35\%. Dinas Kesehatan mendominasi dalam penyelenggaraan pelayanan program KIA $(77,21 \%)$. Puskesmas menyelenggarakan pelayanan program KIA hanya sebesar 8,89\%. Penyelenggara administrasi lainnya dalam hal ini LSM juga turut menyelenggarakan pelayanan KIA
$(4,28 \%)$. Badan pemberdayaan perempuan dan KB yang disebut sebagai DP3AKB merupakan penyelenggara pelayanan yang paling sedikit terhadap program KIA $(1,81 \%)$.

Gambaran fungsi kesehatan (health care function), program kesehatan (health program), jenis kegiatan (health activity), dan mata anggaran (health input)

Fungsi kesehatan adalah dimensi Health Account yang mengidentifikasi anggaran kesehatan sesuai dengan fungsinya. Dimensi program ditujukan untuk mengidentifikasi dengan klasifikasi program kesehatan masyarakat, program kesehatan individu, dan penguatan sistem kesehatan. Sementara jenis kegiatan adalah untuk mengklasifikasi kegiatan yang diselenggarakan dengan jenis kegiatan langsung atau kegiatan tidak langsung. Mata anggaran adalah dimensi yang digunakan untuk mengidentifikasi jenis input yang dibeli baik investasi, operasional, dan pemeliharaan. 
Tabel 2. Fungsi Kesehatan, Program Kesehatan,Jenis Kegiatan dan Mata Anggaran

\begin{tabular}{|c|c|c|c|}
\hline Kode & Fungsi Kesehatan & Jumlah Belanja (Rp) & $\%$ \\
\hline HC.1 & Pelayanan Kuratif & 3.777 .717 .000 & 8,05 \\
\hline HC.4 & Pelayanan Penunjang & 29.726 .835 .000 & 63,37 \\
\hline HC.6 & $\begin{array}{l}\text { Pelayanan Pencegahan dan Kesehatan } \\
\text { Masyarakat }\end{array}$ & 13.055 .232 .255 & 27,83 \\
\hline \multirow[t]{3}{*}{ HC.7 } & $\begin{array}{l}\text { Tata Kelola Sistem Kesehatan dan Administrasi } \\
\text { Pembiayaan Kesehatan }\end{array}$ & 352.600 .000 & 0,75 \\
\hline & Grand Total & 46.912.384.255 & 100,00 \\
\hline & Program Kesehatan & Jumlah Belanja (Rp) & $\%$ \\
\hline PR.1 & Program Kesehatan Masyarakat & 7.132 .158 .015 & 15,20 \\
\hline PR.2 & Program Kesehatan Individu & 3.177 .717 .000 & 6,77 \\
\hline \multirow[t]{3}{*}{$\overline{P R .3}$} & Program Penguatan Sistem Kesehatan & 36.602 .509 .240 & 78,02 \\
\hline & Grand Total & 46.912 .384 .255 & 100,00 \\
\hline & Jenis Kegiatan & Jumlah Belanja (Rp) & $\%$ \\
\hline HA.1 & Kegiatan Tidak Langsung & 35.746 .528 .240 & 76,20 \\
\hline \multirow[t]{3}{*}{ HA.2 } & Kegiatan Langsung & 11.165 .856 .015 & 23,80 \\
\hline & Grand Total & 46.912.384.255 & 100,00 \\
\hline & Mata Anggaran & Jumlah Belanja (Rp) & $\%$ \\
\hline HI.1 & Investasi & 25.973 .550 .615 & 55,37 \\
\hline HI.2 & Operasional & 20.841 .483 .640 & 44,43 \\
\hline \multirow[t]{2}{*}{ HI.3 } & Pemeliharaan & 97.350 .000 & 0,21 \\
\hline & Grand Total & 46.912 .384 .255 & 100,00 \\
\hline
\end{tabular}

Berdasarkan Tabel 2 transportasi pasien dan kedaruratan merupakan fungsi kesehatan yang memiliki jumlah belanja terbesar $(63,37 \%)$ yang hal tersebut masuk dalam pelayanan penunjang. program Konseling Informasi dan Edukasi (KIE) $(16,95 \%)$ dan program pemantauan status kesehatan $(10,88 \%)$ yang keduanya masuk kedalam pelayanan pencegahan dan kesehatan masyarakat. Fungsi kesehatan pada pelayanan kuratif sebesar $5,99 \%$ untuk rawat inap dan 2,06\% untuk rawat jalan. Administrasi pembiayaan kesehatan menjadi fungsi kesehatan yang jumlah belanjanya paling sedikit $(0,75 \%)$.

Program penguatan sistem kesehatan $(78,02 \%)$ mendominasi dalam program KIA di Kabupaten Jember yang didalamnya terdapat program perencanaan dan pengadaan $(61,14 \%)$, penguatan sistem informasi $(8,37 \%)$, peningkatan kapasitas SDM $(1,23 \%)$, pembinaan kader $(3,18 \%)$, jaminan kesehatan $(4,10 \%)$. Sedangkan program kesehatan individu terdiri dari rawat jalan $(2,06 \%)$ dan rawat inap $(4,71 \%)$. Program kesehatan masyarakat merupakan program yang didalamnya terdapat program suveilans $(0,88 \%)$, pelayanan promosi kesehatan $(4,44 \%), \mathrm{KB}(1,81 \%)$, gizi $(4,97 \%)$, dan KIA $(3,11 \%)$.

Kegiatan yang banyak dianggarkan adalah kegiatan tidak langsung (76,20\%) dengan komponen kegiatan antara lain pengadaan dan pemeliharaan infrastruktur $(50,45 \%)$, peningkatan kesejahteraan pegawai $(23,28 \%)$, supervisi $(0,23 \%)$, manajerial dan koordinasi $(0,16 \%)$, pendidikan personil $(1,64 \%)$, dan perencanaan program $(0,46 \%)$. Sementara untuk kegiatan langsung hanya sebesar $23,80 \%$ dari total anggaran, yang didalamnya terdapat kegiatan promosi kesehatan (8,22\%), penemuan dan pemantauan kasus $(9,28 \%)$, dan tindakan medis $(6,30 \%)$.

Belanja pada mata anggaran didominasi oleh belanja investasi dengan belanja untuk pengadaan kendaraan $(49,33 \%)$ dan 
pengadaan alat non medis $(6,03 \%)$. Sementara untuk belanja operasional hanya sebesar $44,43 \%$ dengan didominasi oleh anggaran untuk honorarium $(23,28 \%)$. Adapun belanja yang lain pada belanja operasional antara lain belanja untuk bahan medis habis pakai $(6,23 \%)$, ATK $(0,40 \%)$, perjalanan $(3,86 \%)$, akomodasi $(0,22 \%)$, utilities $(1,10 \%)$, belanja jasa $(1,29 \%)$ dan belanja barang dan jasa lainnya sebesar $8,04 \%$.
Gambaran jenjang kegiatan (level of activity) dan penerima manfaat (health beneficiaries)

Jenjang kegiatan merupakan dimensi Health Account untuk mengidentifikasi jenjang administrative dimana kegiatan dilaksanakan. Sedangkan penerima manfaat adalah seseorang ataupun masyarakat yang menerima manfaat secara langsung maupun tidak langsung dari suatu program/kegiatan kesehatan

Tabel 3. Jenjang Kegiatan dan Penerima Manfaat

\begin{tabular}{lllr}
\hline Kode & \multicolumn{1}{c}{ Jenjang Kegiatan } & Jumlah Belanja (Rp) & $\%$ \\
\hline HL.3 & Kabupaten & 11.264 .073 .900 & 24,01 \\
\hline HL.4 & Kecamatan/Puskesmas & 7.024 .475 .355 & 14,97 \\
\hline HL.5 & Desa/Kelurahan/masyarakat & 28.623 .835 .000 & 61,02 \\
\hline & Grand Total & $\mathbf{4 6 . 9 1 2 . 3 8 4 . 2 5 5}$ & $\mathbf{1 0 0 , 0 0}$ \\
\hline \multicolumn{1}{c}{ Penerima Manfaat } & Jumlah Belanja (Rp) & $\%$ \\
\hline HB.1 & $0-<1$ tahun (bayi) & 52.000 .000 & $0,11 \%$ \\
\hline HB.2 & $1-5$ tahun (balita) & 2.362 .202 .000 & $5,04 \%$ \\
\hline HB.5 & $19-$ 64 tahun (usia produktif) & 11.949 .247 .255 & $25,47 \%$ \\
\hline HB.8 & Kelompok Umur belum dipilah & 32.548 .935 .000 & $69,38 \%$ \\
\hline & Grand Total & $\mathbf{4 6 . 9 1 2 . 3 8 4 . 2 5 5}$ & $\mathbf{1 0 0 , 0 0}$ \\
\hline
\end{tabular}

Berdasarkan Tabel 3 kegiatan pada program KIA di Kabupaten Jember lebih banyak diselenggarakan pada tingkat desa $(61,02 \%)$ dibandingkan pada tingkat Puskesmas atau kecamatan (14,97\%). Sedangkan untuk kegiatan yang dilakukan di tingkatan Kabupaten/Kota sebesar $24,01 \%$. Sedangkan untuk penerima manfaat program KIA di Kabupaten Jember terbesar dilakukan pada kelompok umur yang belum dipilah $(69,38 \%)$, dalam artian kelompok umur usia produktif, bayi, dan balita menjadi penerima manfaat secara bersamaan. Sedangkan untuk program KIA yang penerima manfaatnya kelompok umur usia produktif sebesar 25,47\%, pada kasus ini yang dimaksud kelompok umur usia produkitf adalah ibu hamil, ibu melahirkan, ibu nifas, dan ibu menyusui. Kelompok umur nol sampai dengan kurang dari satu tahun (Bayi) menjadi kelompok yang meneri manfaat terkecil $(0,11 \%)$.

Analisis Pembiayaan Berdasarkan Program Kesehatan dan Mata Anggaran Analisis dilakukan dengan mentabulasi silang antara dimensi program dengan dimensi mata anggaran. Hal ini dilakukan untuk mengetahui jenis input yang dibeli pada setiap program.

Tabel 4. Program Kesehatan dan Mata Anggaran

\begin{tabular}{lcccccc}
\hline \multicolumn{1}{c}{ Mata } & Investasi & $\%$ & Operasional & $\%$ & Pemeliharaan & $\%$ \\
$\begin{array}{l}\text { Anggaran/ } \\
\text { Program }\end{array}$ & & & & & & \\
\hline $\begin{array}{l}\text { Program } \\
\text { Kesehatan }\end{array}$ & 938.465 .615 & 2,00 & 6.193 .692 .400 & 13,21 & 0 & 0 \\
Masyarakat & & & & & & \\
\hline
\end{tabular}




\begin{tabular}{lllllll}
\hline $\begin{array}{l}\text { Program } \\
\text { Kesehatan } \\
\text { Individu }\end{array}$ & 0 & 0 & 3.177 .717 .000 & 6,77 & 0 & 0 \\
\hline $\begin{array}{l}\text { Penguatan } \\
\text { Sistem }\end{array}$ & 25.035 .085 .000 & 53,36 & 11.470 .074 .240 & 24,45 & 97.350 .000 & 0,21 \\
Kesehatan & & & & & & \\
\hline Grand Total & $\mathbf{2 5 . 9 7 3 . 5 5 0 . 6 1 5}$ & $\mathbf{5 5 , 3 6}$ & $\mathbf{2 0 . 8 4 1 . 4 8 3 . 6 4 0}$ & $\mathbf{4 4 , 4 3}$ & $\mathbf{9 7 . 3 5 0 . 0 0 0}$ & $\mathbf{0 , 2 1}$ \\
\hline
\end{tabular}

Berdasarkan Tabel 4 Dapat diketahui belanja investasi untuk pengutan sistem kesehatan menjadi terbesar yang didalamnya didominasi oleh perencanaan dan pengadaan $(49,46 \%)$. Selanjutnya adalah belanja operasional untuk perencanaan dan pengadaan (11,86\%). Sedangkan program penguatan sistem informasi yang termasuk dalam program penguatan sistem kesehatan memiliki belanja investasi sebesar 3,62\%, operasional 4,54\%, dan pemeliharaan $0,21 \%$. Program penguatan sistem kesehatan juga memiliki beberapa komponen program antara lain peningkatan kapasitas SDM yang belanja operasionalnya sebesar $1,23 \%$, pelatihan kader dengan belanja operasional $0,15 \%$ dan belanja investasi $3.03 \%$, dan jaminan kesehatan dengan belanja operasional sebesar $0,13 \%$ dan belanja investasi sebesar 3,97\%. Program kesehatan individu memiliki dua program yaitu rawat jalan dan rawat inap dengan masing-masing memiliki belanja operasional sebesar $2,06 \%$ dan $4,71 \%$. Program kesehatan masyarakat memiliki belanja operasional sebesar $13,21 \%$ dengan 2,08\% untuk KIA, 4,97\% untuk gizi, $1,81 \%$ untuk KB, $3,47 \%$ untuk promosi kesehatan, dan $0,88 \%$ untuk surveilans. Sedangkan pada belanja investasi program kesehatan masyarakat sebesar $2,00 \%$ dengan belanja investasi $1,03 \%$ untuk KIA, dan 0,97\% untuk promosi kesehatan.

\section{Analisis Pembiayaan Berdasarkan Jenis Kegiatan dan Mata Anggaran}

Analisis dilakukan dengan mentabulasi silang antara dimensi jenis kegiatan dengan jenis mata anggaran. Tujuan dilakukannya adalah untuk mengetahui jenis input yang dibeli oleh penyelenggara pelayanan kesehatan pada setiap jenis kegiatannya.

Tabel 5. Jenis Kegiatan dan Mata Anggaran

\begin{tabular}{lllll}
\hline $\begin{array}{c}\text { Jenis Kegiatan/Mata } \\
\text { Anggaran }\end{array}$ & Tidak Langsung & $\%$ & Langsung & $\%$ \\
\hline Investasi & 23.206 .685 .000 & 49,47 & 2.766 .865 .615 & 5,90 \\
\hline Operasional & 12.539 .843 .240 & 26,73 & 8.301 .640 .400 & 17,70 \\
\hline Pemeliharaan & 0 & 0 & 97.350 .000 & 0,21 \\
\hline Grand Total & $\mathbf{3 0 . 4 5 6 . 6 8 7 . 2 4 0}$ & $\mathbf{6 4 , 9 2}$ & $\mathbf{1 6 . 4 5 5 . 6 9 7 . 0 1 5}$ & $\mathbf{3 5 , 0 8}$ \\
\hline
\end{tabular}

Berdasarkan Tabel 5 dapat diketahui bahwa jenis kegiatan dan mata anggaran yang terbesar adalah untuk belanja investasi pada kegiatan tidak langsung $(49,47 \%)$. Selanjutnya adalah belanja operasional untuk kegiatan tidak langsung (26,73\%). Belanja operasional untuk kegiatan langsung hanya sebesar $17,70 \%$, dapat dikatakan bahwa belanja investasi untuk kegiatan tidak langsung lebih besar dari pada belanja operasional untuk kegiatan langsung. Belanja pemeliharaan untuk kegiatan langsung hanya sebesar $0,21 \%$ dan menjadi yang terkecil.

\section{Pembahasan}

Sumber biaya (financing sources), pengelola anggaran (financing agent), dan penyelenggara pelayanan (health provider) Sumber pembiayaan terbesar pada program KIA di Kabupaten Jember berasal dari APBD 
sebesar 95,72\%. Dana APBD yang digunakan berasal dari Dana Alokasi Umum (DAU) dan Dana Alokasi Khusus (DAK), terdapat juga DAK Non Fisik berupa dana Bantuan Operasional Penyelenggaraan Pendidikan Anak Usia Dini (BOP PAUD) dan dana Bantuan Operasional Keluarga Berencana (BOKB). Pendanaan yang bersumber dari swasta adalah berupa donor yang berasal dari bantuan luar negeri. LSM GAIN merupakan lembaga swasta internasional yang pendanaannya berasal dari pemerintah luar negeri. LSM menggunakan dana tersebut untuk melakukan konseling terkait KIA, tujuannya adalah untuk merubah perilaku pada kelompok yang terkategori dalam program KIA, baik itu masyarakat, kader, tenaga medis, dan lain sebagainya. Penyelenggara pelayanan yang terbesar adalah Dinas Kesehatan $(77,21 \%)$, sedangkan untuk puskesmas hanya sebesar $8,89 \%$ dan rumah sakit sebesar 2,83\%. Dalam hal ini penyelengaraan pelayanan di rumah sakit hanya sebatas dari dana jampersal dan pelayanan $\mathrm{KB}$, bukan penyelenggaraan pelayanan KIA yang dilakukan rumah sakit secara utuh. Penyelenggaraan pelayanan yang dilakukan oleh Dinas Kesehatan, puskesmas, dan rumah sakit jika ditinjau dengan Permenkes RI No 75 Tahun 2014 maka hal tersebut sesuai dengan amanah peraturan yang berlaku. Dinas Pendidikan bukan termasuk pengelola dan penyelenggara pelayanan yang dominan terkait program KIA. Hal ini sesuai dengan Permendikbud Nomor 2 Tahun 2018 bahwa salah satu komponen pembiayaan pada BOP PAUD adalah untuk kegiatan pendukung yaitu pemberian makanan sehat. Sementara pada DP3AKB penyelenggaraan pelayanan KIA berasal dari dana BOKB tidak dapat berjalan dengan optimal, hal ini dikarenakan adanya ketidak sinkronan antara kebijakan pada Peraturan BKKBN Nomor 21 Tahun 2018 yang mengatur tentang penggunaan dana BOKB dengan kebijakan kepala daerah hingga berakhirnya tahun anggaran.
Fungsi kesehatan (health care function), program kesehatan (health program), jenis kegiatan (health activity), dan mata anggaran (health input)

Hasil penelitian yang telah dilakukan menunjukkan bahwa transportasi pasien dan kedaruratan merupakan fungsi kesehatan yang terbesar $(63,37 \%)$, hal tersebut tergolong dalam pelayanan penunjang. Pelayanan promotif dan preventif $(27,83 \%)$ jauh lebih besar jika dibandingkan dengan pelayanan kuratif $(8,05 \%)$. Akan tetapi jika pelayanan promotif dan preventif dibandingkan dengan pelayanan penunjang tentu jauh lebih besar untuk fungsi pelayanan penunjang, yaitu untuk pelayanan transportasi pasien dan kedaruratan. Tujuan dari pelayanan penunjang pada transportasi pasien dan kedaruratan adalah untuk mempermudah dalam proses rujukan saat keadaan darurat dari desa ke fasilitas pelayanan kesehatan. Pembiayaan pada Program Konseling Informasi dan Edukasi serta Program Pemantauan Status Kesehatan seharusnya menjadi prioritas, dimana hal ini tergolong dalam upaya promotif dan preventif. Pencegahan, pemberian informasi, deteksi dini, serta pemantauan perkembangan kasus merupakan upaya yang penting untuk dilakukan. Adanya informasi yang cukup yang didapatkan oleh masyarakat dapat memungkinkan masyarakat untuk lebih waspada dan mengubah perilakunya sehingga dapat menekan kasus AKI dan AKB (Handayani et al., 2013). Upaya promotif dan preventif juga merupakan investasi bagi pembangunan SDM. Perubahan perilaku dari masyarakat untuk sadar melakukan pola hidup sehat dapat membantu dalam pembangunan kesehatan (Larasanti, 2017).

Program kesehatan memiliki tujuan untuk menggambarkan jenis program yang dibiaya oleh pengelola anggaran. Program yang dimaksud terkategori dalam program kesehatan masyarakat, program kesehatan individu, serta program penguatan sistem kesehatan. Kabupaten Jember dalam hal KIA 
menjadikan program penguatan sistem kesehatan sebagai piroritas (78,02\%). Perencanaan dan pengadaan memiliki anggaran terbesar dalam program tersebut $(61,14 \%)$. Besarnya anggaran perencanaan dan pengadaan disebabkan adanya program pengadaan ambulan untuk setiap desa di Kabupaten Jember. Sementara untuk upaya dalam program kesehatan masyarakat (UKM) hanya sebesar $15,20 \%$. Program kesehatan individu (UKP) hanya berupa pelayanan rawat jalan dan rawat inap yang berasal dari program Jampersal dan juga berasal dari program KB yaitu berupa Metode Operasi Wanita (MOW) dan Metode Operasi Pria (MOP). Program penguatan sistem kesehatan sangat diperlukan untuk meningkatkan kualitas serta menjamin terselenggaranya penyediaan layanan publik yang salah satunya adalah pelayanan kesehatan. Hal tersebut sesuai dengan mandat dari Undang-Undang Nomor 25 Tahun 2009 tentang Pelayanan Publik. Akan tetapi dalam pelaksanaan pelayanan kesehatan juga terdapat peraturan yang bersifat khusus yang mengatur tentang prioritas arah kebijakan pelaksanaan pelayana kesehatan. Aturan tersebut tertuang dalam Permenkes RI Nomor 39 Tahun 2016 yang mengatur untuk mengintegrasikan UKM dan UKP secara berkesinambungan.

Berdasarkan hasil penelitian pada program KIA di Kabupaten Jember berdasarkan jenis kegiatan menunjukkan bahwa proporsi anggaran terbesar dialokasikan untuk jenis kegiatan tidak langsung $(76,20 \%)$. Sedangkan untuk kegiatan langsung hanya sebesar 23,80\%. Alokasi belanja yang terbesar pada kegiatan tidak langsung berada pada pengadaan dan pemeliharaan infrastruktur serta peningkatan kesejahteraan pegawai. Kegiatan langsung dapat dibedakan menjadi dua yaitu kegiatan pelayanan perorangan dan kegiatan kesehatan masyarakat. Kegiatan pelayanan perorangan dapat berupa tindakan medis, sedangkan untuk kegiatan kesehatan masyarakat seperti misalnya promosi kesehatan serta penemuan dan pemantaun kasus. Kegiatan tidak langsung dapat diartikan sebagai kegiatan yang dilakukan dengan tujuan untuk menunjang dua kelompok kegiatan langsung tersebut (PPJK Kemenkes \& PKEKK FKM UI, 2016). Jika dilihat dengan pendekatan anggaran berbasis kinerja (Performanced Based Budgeting) maka pendekatan ini tidak menekankan pada seberapa besar anggaran yang diserap akan tetapi seberapa besar kebermanfaatan yang dapat dipertanggung jawabkan dalam setiap rupiah yang dikeluarkan (Kurrohman, 2013). Sehingga setiap kegiatan yang direncanakan harus memiliki nilai kebermanfaatan yang jelas. Kegiatan-kegiatan yang sifatnya tidak langsung tidak dapat menghasilkan keluaran dan hasil nyata yang optimal, sehingga perlu adanya evaluasi dengan tujuan lebih banyak merencanakan kegiatan yang bersifat langsung.

Mata anggaran adalah klasifikasi pada jenis input yang dibeli oleh penyelenggara pelayanan. Klasifikasi belanja jika dilihat dari mata anggaran pada program KIA di Kabupaten Jember maka yang terbesar adalah untuk belanja investasi $(55,37 \%)$. Sementara untuk belanja operasional hanya sebesar 44,43\%. Menurut Nugraheni et al., (2012) perlu kiranya dilakukan penurunan alokasi pembiayaan kesehatan untuk belanja investasi, sehingga anggaran dapat dialokasikan pada belanja operasional yang secara langsung dapat menunjang program-program kesehatan. Besarnya anggaran untuk belanja investasi akan membuat menurunnya anggaran untuk belanja operasional. Padahal alokasi belanja yang besar untuk belanja investasi cenderung tidak meningkatkan kinerja (PPJK Kemenkes \& PKEKK FKM UI, 2016). Pencapaian target suatu program juga dapat diketahui dari belanja operasional. Berdasarkan pendekatan Anggaran Berbasis Kinerja (ABK) alokasi untuk belanja operasional menjadi determinan dalam kinerja suatu program. Pendekatan ABK memiliki prinsip bahwa efisiensi tidak 
untuk menekan efektifitas, akan tetapi efektifitas tidak harus dengan pemborosan (Ramli, 2013). Pola belanja yang sebagian besar ditujukan untuk belanja modal perlu kiranya dipertimbangkan, seperti halnya belanja untuk program ambulan desa. Mengingat pola belanja yang memprioritaskan untuk belanja modal dimungkinkan tidak menghasilkan keluaran yang signifikan.

Jenjang kegiatan (level of activity) dan penerima manfaat (health beneficiaries)

Berdasarkan hasil penelitian jenjang kegiatan untuk program KIA di Kabupaten Jember banyak dilakukan di tingkat desa $(61,02 \%)$. Hal ini disebabkan adanya anggaran yang terlalu besar untuk pengadaan ambulan desa, bukan karena banyaknya kegiatan langsung yang dilakukan di desa. Terdapat juga kegiatan yang dilakukan pada tingkat puskesmas dan kecamatan, serta pada tingkat kabupaten akan tetapi lebih banyak anggaran untuk desa. Seharusnya anggaran banyak difokuskan pada tingkat puskesmas, karena puskesmas merupakan upaya pelayanan kesehatan pertama yang juga mudah terjangkau oleh masyarakat. Dapat diketahui juga bahwa puskesmas saat ini menjadi ujung tombak dalam memberikan pelayanan kesehatan terhadap masyarakat. Sehingga institusi yang bertanggung jawab dalam membuat kebijakan perlu memprioritaskan upaya kesehatan pada jenjang puskesmas dengan tuntutan untuk memenuhi kepentingan dan permasalahan kesehatan yang ada di masyarakat (Wardani, 2014).

Penerima manfaat merupakan sekelompok orang yang meneri manfaat secara langsung maupun tidak langsung dari suatu program kesehatan. Berdasarkan hasil penelitian bayi menjadi kelompok terkecil dalam penerimaan manfaat $(0,11 \%)$. Hal ini bukan dikarenakan sedikitnya program untuk bayi akan tetapi terdapat program yang penerima manfaatnya terkategori sebagai kelompok yang tidak dapat dipilah $(69,38 \%)$. Program KIA yang dilakukan banyak penerima manfaatnya bersamaan antara bayi, balita, ibu hamil, ibu melahirkan, ibu menyusui, dan ibu nifas. Sehingga belum dapat dipastikan anggaran sebenarnya untuk kelomok umur bayi dan balita. Pembiayaan untuk pelayanan kesehatan bagi bayi dan balita sangat perlu untuk diperhatikan. Pembiayaan kesehatan untuk ibu dan bayi merupakan "Human Investment" karena kelompok umur tersebut memiliki peranan penting dalam pembangunan jangka panjang (Syamruth, 2013). Menurut Bahri (2011) kualitas dari sumber daya manusia menjadi faktor penentu perjalanan daya saing suatu bangsa.

\section{Pembiayaan Berdasarkan Program Kesehatan dan Mata Anggaran}

Berdasarkan hasil penelitian didapatkan bahwa pada program KIA di Kabupaten Jember dana terbesar dialokasikan untuk belanja investasi pada program penguatan sistem kesehatan $(53,36 \%)$, sedangkan untuk belanja operasionalnya sebesar $24,25 \%$, yang mana anggaran tersebut banyak dihabiskan untuk honorarium. Sementara belanja operasional untuk UKM dan UKP lebih kecil jika dibandingkan pada belanja untuk program penguatan sistem kesehatan. Belanja operasional untuk UKM hanya sebesar $13,21 \%$ dan UKP hanya sebesar $6,77 \%$. UKM dan UKP tergolong sebagai kegiatan langsung dimana manfaatnya dapat secara langsung diterima oleh masyarakat, sehingga program tersebut sangat memerlukan belanja operasional yang besar.

Pembiayaan Berdasarkan Jenis Kegiatan dan Mata Anggaran

Belanja investasi pada kegiatan tidak langsung $(49,47 \%)$ menjadi prioritas pada program KIA di Kabupaten Jember. Beberapa kegiatan yang dilaksanakan anggarannya banyak diperuntukkan untuk belanja modal. Belanja terbesar kedua selanjutnya adalah belanja operasional untuk kegiatan tidak langsung (26,73\%). Sedangkan belanja operasional untuk kegiatan langsung tergolong rendah hanya sebesar $(17,70 \%)$. Permasalahan yang 
kerap terjadi pada sistem pembiyaan kesehatan adalah pola belanja yang cenderung pada belanja investasi untuk kegiatan tidak langsung. Ketika belanja investasi untuk kegiatan tidak langsung menjadi prioritas maka akan berdampak terhadap jumlah anggaran yang semakin sedikit untuk belanja operasional pada kegiatan langsung (PPJK Kemenkes \& PKEKK FKM UI, 2016). Akibatnya kinerja program KIA di Kabupaten Jember belum optimal hal tersebut disebabkan oleh perencanaan kegiatan dan pola belanja yang belum tepat. Perlu adanya perbaikan terhadap perencanaan kegiatan dan perilaku belanja pada setiap penyelenggara pelayanan.

\section{Kesimpulan dan Saran Kesimpulan}

Sumber Pembiayaan program KIA di Kabupaten Jember sebagian besar berasal dari APBD dimana dana tersebut sebagian besar berasal dari DAU dan DAK, dengan pengelola anggaran dan penyelenggara pelayanan didominasi oleh Dinas Kesehatan, sedangkan fungsi kesehatan terbesar adalah transportasi pasien dan kedaruratan yang difungsikan untuk rujukan pasien, program kesehatan terbesar ada pada program penguatan sistem kesehatan yang sifatnya sebagai penunjang, adapun kegiatan yang lebih banyak dilaksanakan adalah kegiatan yang bersifat tidak langsung, selain itu pola belanja pada mata anggaran lebih banyak digunakan untuk belanja investasi dengan kegiatan terbanyak dilaksanakan pada tingkat desa, sedangkan kelompok umur yang banyak menerima manfaat adalah kelompok umur belum dipilah dalam artian kelompok usia produktif, bayi dan balita secara bersamaan meneri manfaat suatu kegiatan. Pola belanja pada setiap program kesehatan banyak digunakan untuk belanja investasi dengan belanja terbesar berada pada program perencanaan dan pengadaan, sehingga belanja operasional untuk program UKM dan UKP sangat terbatas. Mata anggaran pada kegiatan program KIA banyak diprioritaskan untuk belanja investasi pada kegiatan tidak langsung, akibatnya adalah belanja operasional untuk kegiatan langsung sangat terbatas yang berdampak terhadap kinerja program yang tidak optimal.

\section{Saran}

Pemerintah Kabupaten Jember harus melakukan pola perencaan kebijakan kesehatan berlandaskan pada paradigma sehat yang memprioritaskan pada fungsi pelayanan kesehatan bersifat promotif dan preventif, sehingga RPJMD yang disusun harus diarahkan kepada pembangunan berparadigma sehat. Pemerintah Kabupaten Jember juga seharusnya melakukan perencanaan anggaran berbasis kinerja (performance based budgeting) dan berbasis data (evidence based) dengan membangun sistem informasi manajemen keuangan daerah yang terintegrasi. Pemerintah Kabupaten Jember juga seharusnya mengembangkan Health Account secara menyeluruh, dengan membuat payung hukum untuk melembagakan pelaksanaan Health Account ditingkat daerah untuk menjadi dasar dalam perencanaan dan pengalokasian anggaran kesehatan di Kabupaten Jember.

\section{Daftar Pustaka}

Agustina, Bahri, Z. 2011. Analisis Produktifitas Investasi Sumber Daya Manusia Melalui Sarana Pendidikan dan Pelatihan di Kota Jambi. Jurnal Paradigma Ekonomika, 3 (1): 31.

Departemen Kesehatan. 2017. Profil Kesehatan Indonesia Tahun 2016. Jakarta: Depkes RI

Dinas Kesehatan Kabupaten Jember. 2018. Profil Kesehatan Kabupaten Jember Tahun 2017. Jember: Dinas Kesehatan Kabupaten Jember.

Handayani et al., 2013. Pemanfaatan Jaminan Persalinan untuk Pelayanan Kesehatan Ibu dan Anak di 12 Kabupaten/Kota: Mengeliminasi Kendala Sosial Budaya dalam Persalinan Aman. Buletin Penelitian Sistem Kesehatan, 16 (4): 425-426. 
International Labour Organization. 2018. Tujuan Pembangunan Berkelanjutan Referensi Manual Serikat Pekerja untuk Agenda Pembangunan Berkelanjutan 2030. Jakarta: ILO.

Kurrohman, T. 2013. Evaluasi Penganggaran Berbasis Kinerja Melalui Kinerja Keuangan yang Berbasis Value for Money di Kabupaten/Kota di Jawa Timur. Jurnal Dinamika Akutansi, 5 (1): 2.

Larasanti, A. 2017. Pelaksanaan Promosi Kesehatan Rumah Sakit di RSU Haji Surabaya. Jurnal Promkes, 5 (2): 118.

Nugraheni et al., 2012. Studi Pembiayaan Kesehatan Kabupaten Seram Bagian Barat Propinsi Maluku. Jakarta: Kementerian Kesehatan Republik Indonesia.

Organization for Economic Co-operation and Development. 2017. A System of Health Accounts 2011 Revised Edition. Paris: OECD.

Priagung \& Mafudi. 2016. Pengaruh Penyerapan Anggaran, Budaya Organisasi, Kepuasan Kerja dan Pengawasan Inspektorat Terhadap Kinerja Keuangan Organisasi Publik (Studi pada Pemerintah Daerah Kabupaten Banjarnegara). Jurnal Ekonomi dan Bisnis Islam, 2 (1): 2-3.

Pusat Pembiayaan dan Jaminan Kesehatan Kemenkes RI dan Pusat Kajian Ekonomi dan Kebijakan Kesehatan Fakultas Kesehatan Masyarakat Indonesia. 2016. Modul dan Pedoman Pelatihan District Health Account (DHA) Edisi 3. Jakarta: Pusat Kajian Ekonomi dan Kebijakan Kesehatan FKM UI.

Ramli, S. 2013. Bacaan Wajib Para Praktisi Pengadaan Barang/Jasa Pemerintah. Jakarta: Visimedia.

Republik Indonesia, 2009. Undang-Undang RI Nomor 25 Tahun 2009 Tentang Pelayanan Publik. Jakarta.

R., Dartanto, T., Sitompul, R., Susiloretni, K. A., Suparmi, S., Achadi, E. L., $\ldots$ Thabrany, H. (2018). Universal Health Coverage in Indonesia: Concept, Progress, and Challenges. The Lancet,
Republik Indonesia, 2014. Peraturan Menteri Kesehatan Nomor 75 Tahun 2014 Tentang Pusat Kesehatan Masyarakat. Jakarta.

Republik Indonesia, 2016. Peraturan Menteri Kesehatan Nomor 39 Tahun 2016 Tentang Pedoman Penyelenggaraan Program Indonesia Sehat dengan Pendekatan Keluarga. Jakarta.

Republik Indonesia, 2018. Peraturan Badan Kependudukan dan Keluarga Berencana Nasional Nomor 21 Tahun 2018 Tentang Petunjuk Operasional Penggunaan Dana Alokasi Khusus Subbidang Keluarga Berencana. Jakarta.

Republik Indonesia, 2018. Peraturan Menteri Pendidikan dan Kebudayaan Nomor 2 Tahun 2018 Tentang Petunjuk Teknis Penggunaan Dana Alokasi Khusus Nonfisik Bantuan Operasional Penyelenggaraan Pendidikan Anak Usia Dini Tahun 2018. Jakarta.

Syamruth, Y. 2014. Pivot Table Analisis Biaya Program Gizi dengan Perspektif District Health Account (Studi di Kabupaten Sumba Timur tahun 2013). Jurnal Info Kesehatan, 13 (2): 750.

Wardani, R. 2014. Analisis Penetapan Prioritas Program Upaya Kesehatan Dasar (Puskesmas) pada Tingkat Pemerintah Daerah (Studi Eksploratif di Kota Bogor Tahun 2013). Jurnal Kebijakan Kesehatan Indonesia, 3 (4): 200-201.

Zakeri, M., Olyaeemanesh, A., Zanganeh, M., Kazemian, M., Rashidian, A., Abouhalaj, M., Tofighi, S. 2015. The Financing of the Health System in the Islamic Replubic of Iran: a National Health Account (NHA) Approach. Medical Journal of the Islamic Republic of Iran, 29 (243):2.

(18). https://doi.org/10.1016/S01406736(18)31647-7

Andi, F. A. (2015). Analysis of National Health Insurance Towards A Universal Health Insurance. Kajian Ekonomi Dan Keuangan, 19(1), 63-78. 
BPJS Kesehatan. (2014). Seputar BPJS Kesehatan.

Cawley, J., \& Ruhm, C. J. (2012). The Economics of Risky Health Behaviors. In Handbook of Health Economics, Volume 2 (Vol. 2). https://doi.org/10.1016/B9780-444-53592-4.00003-7

Courtemanche, C., Marton, J., Ukert, B., Yelowitz, A., \& Zapata, D. (2018). Early Effects of the Affordable Care Act on Health Care Access, Risky Health Behaviors, and Self-Assessed Health. Southern Economic Journal, 84(3), 660 691. https://doi.org/10.1002/soej.12245

Dave, D., Kaestner, R., \& Wehby, G. (2019). Does Medicaid Coverage for Pregnant Women Affect Prenatal Health Behaviors? Journal of Population Economics, 32(2), 419-453. https://doi.org/10.3386/w21049

Dong, W., Gao, J., Zhou, Z., Bai, R., Wu, Y., Su, M., ... Wang, X. (2018). Effects of China's urban basic health insurance on preventive care service utilization and health behaviors: Evidence from the China Health and Nutrition Survey. PLoS ONE, 13(12), 1-14.

Ehrlich, I., \& Becker, G. S. (1972). Market Insurance , Self-insurance, and SelfProtection. Journal of Political Economy, 80(4), 623-648.

Erlangga, D., Ali, S., \& Bloor, K. (2019). The impact of public health insurance on healthcare utilisation in Indonesia: evidence from panel data. International Journal of Public Health, 2(2), 1-11. https://doi.org/10.1007/s00038-01901215-2

Ghislandi, S. (2015). The impact of Universal Health Coverage on Health Care Consumption and Risky Behaviours: Evidence from Thailand. Health Economics, Policy and Law, 10, 251266.

https://doi.org/10.1017/S174413311400 0334
Irwandy. (2016). Kajian Literature: Evaluasi Pelaksanaan Program Jaminan Kesehatan Nasional di Indonesia. Jurnal Kebijakan Kesehatan Indonesia, 05(03), 110-114.

Kann, L., McManus, T., Harris, W. A., Shanklin, S. L., Flint, K. H., Queen, B., \& Lowry, Ri. (2018). Youth Risk Behavior Surveillance - United States, 2017. MMWR Surveill Summ, 67(8), 3114.

Lee, J. (2018). Effects of Health Insurance Coverage on Risky Behaviors. Health Economics, 1-16. https://doi.org/10.1002/hec.3634

Nurmansyah, M. I., \& Kilic, B. (2017). Impact of National Health Insurance Policy towards the Implementation of Health Promotion Program at Public Health Centers in Indonesia. Kesmas: National Public Health Journal, 11(3), 103-110. https://doi.org/10.21109/kesmas.v11i3.1 262

Qin, X., \& Lu, T. (2014). Does Health Insurance Lead to Ex Ante Moral Hazard? Evidence from China's New Rural Cooperative Medical Scheme. The Geneva Papers on Risk and InsuranceIssues and Practice, 39(4), 625-650. https://doi.org/10.1057/gpp.2014.26

Simon, K., Soni, A., \& Cawley, J. (2017). The Impact of Health Insurance on Preventive Care and Health Behaviors: Evidence From The First Two Years of The ACA Medicaid Expansions. Journal of Policy Analysis and Management, 36(2), 390-417. https://doi.org/10.1002/pam.21972

Stanciole, A. E. (2008). Health Insurance and Lifestyle Choices: Identifying Ex Ante Moral Hazard in the US Market. The Geneva Papers on Risk and Insurance Issues and Practice, 33, 627-644. https://doi.org/10.1057/gpp.2008.27

Strauss, J., Witoelar, F., \& Sikoki, B. (2016a). The Fifth Wave of the Indonesia Family 
Life Survey(IFLS5): Overview and Field Report. March 2016.

Strauss, J., Witoelar, F., \& Sikoki, B. (2016b). User's Guide for the Indonesia Family Life Survey, Wave 5 Volume 2. March 2016.

Strauss, J., Witoelar, F., Sikoki, B., \& Wattie, A. M. (2009a). The Fourth Wave of the Indonesia Family Life Survey: Overview and Field Report. March 2009. (No. WR675/1-NIA/NICHD).

https://doi.org/10.7249/WR1143.1

Strauss, J., Witoelar, F., Sikoki, B., \& Wattie, A. M. (2009b). User's Guide for the Indonesia Family Life Survey, Wave 4. Volume 2. March 2009. https://doi.org/10.7249/WR1143.2
Suryanto, B. A., Setihadji, B., \& Syukriani, Y. F. (2017). The Impact of National Health Insurance Program on Household Health Expenditures and Utilization of Health Services in Indonesia.

Willage, B. (2018). Unintended Consequences of Insurance: ACA's Free Contraception Mandate and Risky Sex. Retrieved from http://bartonwillage.com/pages/working _papers/JMP.pdf

Yusuf, E., \& Awwaliyah, I. (2018). The Implementation of Indonesian National Health Insurance Programme: How Satisfied Where The Insured Participants and The Healthcare Providers? Journal of Consumer Sciences, 03(02), 27-42. 